Proceedings of the 2018 International Scientific Conference 'Economic Sciences for Agribusiness and Rural Economy' No 2, Warsaw, 7-8 June 2018, pp. 124-129

\title{
WOMEN'S LABOUR MARKET ACTIVITY IN THE AGRICULTURE SECTOR IN POLAND AND EUROPEAN UNION IN 2016
}

\author{
Aleksandra Matuszewska-Janica, $\mathrm{PhD}^{1}$ \\ Faculty of Applied Informatics and Mathematics, Warsaw University of Life Sciences - SGGW
}

\begin{abstract}
The European authorities pay particular attention to agriculture and employees in this sector. Women represent more than $33 \%$ of this group in the European Union. A significant number of actions are targeted at women from rural areas, having regard to the mentioned issues and specific situation of women in the labour market. Therefore, it requires in-depth analyses. The main aim of the presented study is to assess the diversity of the situation of women working in agriculture across the EU. The quantitative analysis allows to indicate similarities and differences among EU states in the current structure of women's employment in this sector. In the analysis, the $k$-mean method is applied with the Labour Force Survey data from the year 2016. The study refers to $28 \mathrm{EU}$ states and a group of women aged 20-64. The obtained results indicated that we have a large proportion of self-employees in agriculture. However, we observe a larger percentage of those who create jobs for others states that are better economically developed. This analysis confirms the findings that the Polish structure of female employment is closer to those in the Mediterranean countries. Poland is assigned to one cluster with Greece. This group is distinguished by several factors. Firstly, it contains a high proportion of people employed in agriculture with a relatively small share of part-timers. Secondly, it is a very high rate of self-employed with a very low proportion of those who create jobs for others.
\end{abstract}

Keywords: labour market, female employment, cluster analysis, $k$-mean method

JEL codes: J21, C38

\section{INTRODUCTION}

Technological progress, globalisation and economic transition processes are just a few factors that strongly affect changes in employment. This concerns employment in the agriculture sector in particular, which has experienced significant transformations in the recent decades (Klepacki, 2006; Puzio-Wacławik, 2006; Szczukocka, 2012). Women are a specific group in the labour market. They are classified as a group called a 'problem group' - disadvantaged group or excluded group (rynekpracy.org, 2006; Kwiatkowska, 2012). Such issues are widely discussed by Blau et al. (2010) or Sztanderska (2006), among others. These problems concern women living in rural areas, in particular (Sawicka, ed., 2013; Krzyżanowska, 2014). Therefore, this group has a special place in the European labour market policy (Strategy Europe 2020, Strategy for equality between women and men 2010-2015, Strategic Engagement for Gender Equality 2016-2019, European Parliament resolution on the role of women in agriculture and rural areas, among others).

${ }^{1}$ Corresponding author: Nowoursynowska 166, 02-787 Warsaw, Poland, aleksandra_matuszewska@sggw.pl, +48225937254 
The employment of women in agriculture is a multidimensional subject, which is very important both from an economic and a social point of view. It requires conducting comprehensive analyses for monitoring and an evaluation of the situation. This in turn translates to the monitoring and an evaluation of the efficiency of the European labour market policy or to the monitoring of the human capital in the rural areas among others. The main aim of the presented study is to assess the diversity of the current situation of women working in agriculture across the European Union (EU). The verified hypothesis refers to the fact that this situation has still characterised by a considerable heterogeneity. The quantitative analysis firstly allows to indicate the similarities and differences among EU states in the structure of women's employment in this sector. Secondly, it allows to compare the current position of female employees in agriculture in Poland to other EU states. In the study, the following indicators are applied: (1) participation rate of women working in the agriculture sector; (2) the proportion of women in the group of employed in agriculture (feminisation rate); (3) the proportion of self-employed women; (4) the proportion of self-employed women with employees; and (5) the participation rate of part-timers in the group of women working agriculture.

\section{SELECTED ISSUES OF THE LABOUR MARKET RELATED TO AGRICULTURE}

A reduction in the number of jobs in industry and agriculture has been observed in the recent decades. Changes in the occupational structure have been driving the transition from an industry- and agriculturedominated economy to a services-dominated economy (Fisher, 1935; Clark, 1940; Puzio-Wacławik, 2006). Four percent of those employed in the EU (aged 20-64) are people working in agriculture in 2016 according to the Labour Force Survey. Thirtythree percent of this group are women. The Eurostat's statistics also show that these rates are significantly diversified across Europe. One in five people is employed in agriculture in Bulgaria; every tenth in Poland and Greece. But there are countries where the percentage of agriculture employees does not exceed $1.5 \%$ (UK $-0.9 \%$, Belgium - 1.1\%, Germany $1.2 \%$ and Malta $1.3 \%$ ). The most feminised groups of agricultural workers can be found in Austria (44.4\%), Poland (40.1\%) and Romania (40.8\%). In turn, the lowest percentage of women have been observed in Ireland (14\%) and Denmark (19.6\%). Reports of GEOPA-COPA (Employers' Group of Professional Agricultural Organisations in the European Union) pointed to two essential matters. Firstly, there are significant geographical differences in the general situation of people working in agriculture in the EU. Secondly, they show how much the situation of agricultural workers is different from those in other sectors. These differences are primarily influenced by the structure of the economy and the level of economic development of the state. The agriculture sector is characterised by a significant proportion of seasonal workers (Rudra and Biswas, 1973; Kanwar, 2004). This is mainly due to the fact that we observe a significant impact of natural conditions on the functioning of this economic activity. Another distinctive feature of agriculture employees is the large number of self-employed workers. This fact is confirmed by surveys conducted by GEOPA-COPA (2013). They indicate that agriculture is organised into small businesses all across Europe. On the one hand, this indicates the large potential of entrepreneurship of people employed in agriculture (Mularska-Kucharek and Wiktorowicz, 2015). On the other hand, the literature points to the fact that a high percentage of self-employed (especially in Poland) is rather the result of a large share of individual farming in the economy than a particular propensity to undertake self-employment (Kryńska, 2007).

\section{MATERIALS AND METHODS}

The presented analysis uses the publicly available Eurostat's Labour Force Survey (LFS) data from the year 2016. The study refers to $28 \mathrm{EU}$ states and a group of women aged 20-64 (this age range corresponds to the Europe 2020 Strategy). Eurostat classifies economic activities with reference to the Statistical Classification of Economic Activities in the European Community named NACE (NACE Rev. 2 since 2008). The presented analysis concern women employed in section A of the NACE rev. 2 that include agriculture, 
forestry and fishing. This sector will hereinafter be called the agricultural sector in order to simplify the description of the analysis results.

- Variable 1 - The participation rate of working in the agriculture sector in the group of employed women aged 20-64: $\% E F(A)_{i}=\frac{N F(A)_{i}}{N F_{i}} \cdot 100 \%$, where: $N F(A)_{i}$ - number of women working in the agriculture sector in the $i$-th state in 2016, $N F_{i}$ - number of employed women in the $i$-th state in 2016.

- Variable 2-The proportion of women in the group of employed in the agriculture sector (feminisation rate): $\%$ Fem $(A)_{i}=\frac{N F(A)_{i}}{N F(A)_{i}+N M(A)_{i}} \cdot 100 \%$, where: $N M(A)_{i t}-$ number of men working in the agriculture sector in the $i$-th state in 2016

- Variable 3 - The proportion of self-employed in the group of women working in the agriculture sector: \%SELF_F $(A)_{i}=\frac{S E L F \_N F(A)_{i}}{N F(A)_{i}} \cdot 100 \%$, where: $\operatorname{SELF~} N F(A)_{i}$ - number of female self-employees in the agriculture sector in the $i$-th state in 2016.

- Variable 4 - The proportion of self-employed women with employees in the analysed sector: $\% S E L F 2_{-} F(A)_{i}=\frac{S E L F 2 \_N F(A)_{i}}{S E L F \_N F(A)_{i}} \cdot 100 \%$, where: $S E L F 2 \_N F(A)_{i}-$ number of self-employed women with employees in the agriculture sector in the $i$-th state in 2016 .

- Variable 5-The participation rate of part-timers in the in the group of employed women in the agriculture sector: $\% P T_{-} F(A)_{i}=\frac{P T_{-} N F(A)_{i}}{N F(A)_{i}} \cdot 100 \%$, where: $P T \_N F(A)_{i}$ - number of women working part-time in the agriculture sector in the $i$-th state in 2016 .

There was no possibility of including the temporary employment variable because of significant lack of the data in the Eurostat's datasets.

It is applied the $k$-means method (McQueen, 1967; Gatnar and Walesiak, eds., 2004) and Statistica soft- ware for the clustering. The procedure for conducting cluster analysis is taken from the article (Walesiak, 2006). Data was standardized and as a distance measure it was applied Euclidean distance. The $k$-means method is one of the most widely applied methods for data clustering. It consists of dividing the analysed sample of objects into predefined number of cluster. This method consists in dividing the analysed group of objects into predefined number of classes. In the first phase of analysis, objects (states) were divided into different number of clusters: groups: from 2 to $10(k=2,3, \ldots, 10)$. Then, based on silhouette index (SI) (Kaufman and Rousseeuw, 1990), the best divisions were selected. Walesiak (2006) reports that values over 0.5 designated that reasonable structure has been found. then the number of clusters is acceptable.

\section{RESULTS}

The obtained results show a great diversity among EU states with respect to the women's labour market activity in the agriculture sector. Division into 10 clusters is the best with the highest value of the silhouette index SI equalling 0.52. Compositions of the clusters and average values of the variables for each cluster are presented in the Table 1. Four one-object clusters have been obtained: Netherlands (cluster 1), Austria (cluster 2), Malta (cluster 3) and Romania (cluster 4). The Netherlands is distinguished by a low proportion of women working in agriculture (1.2\% of employed women) and a high proportion of women working part-time $(69.3 \%$ of the analysed employees in the Netherlands). The Netherlands has generally a high percentage of female part-timers in comparison to other EU countries $(74.8 \%$ for $20-64$ aged group), where part-timers among women are no more than $48 \%$. It is worth to mention that the Netherlands is also characterised by a great share of self-employed women -- over $52 \%$. The next cluster (where is Austria classified) is distinguished by the highest feminisation rate of employees in agriculture (44.4\%), a high proportion of self-employed (57.3\%) and a considerable percentage of those working part-time $(40.5 \%)$. The lowest percentage of women working in agriculture was obtained for cluster 3 
(Malta, $0.3 \%$ ), whereby the percentage of part-timers is $0 \%$. This cluster is also characterised by the lowest feminisation rate $(8.3 \%)$. It is worth noting that, in other clusters, the average values of this rate where $24 \%$ and greater. Although $50 \%$ of women working in agriculture are self-employed in Malta, the share of those self-employed with employees is equal to $0 \%$. A very low participation of self-employed with employees was obtained for cluster 4 (Romania, 0.5\%). This group is distinguished by the highest proportion of women employed in agriculture $-19.2 \%$. This situation transfers into a high feminisation rate $(40.8 \%)$ in the analysed economic sector.

Poland is classified to the cluster number 6 , together with Greece. This cluster is characterised by a very high percentage of self-employed women in agriculture (almost $65 \%$ on average). Whereby, on average, only $5.8 \%$ of this group create jobs for others. The distinguishing feature of this group is also the fact that every tenth women works in agriculture, but relatively few of them are part-timers $(15.9 \%$ on average). Attention will also be paid to the fact that the feminisation rate is very high (close to $40 \%$ ) in comparison to other clusters. Cluster number 6 consists of two countries: Sweden and Luxembourg. The participation of women in the agriculture sector is $0.7 \%$ on average. This group is characterised by a high rate of self-employed women (57\% on average) with a high percentage of those who employ others (41.9\% on average). Five countries have been classified to cluster 7: Bulgaria, Czech Republic, Estonia, Hungary, Slovenia. A low percentage of part-time employees is characteristic for this group of states ( $11 \%$ on average). Other values of the analysed ratios are at an average level in comparison to the rest of the clusters. Denmark and Germany are classified together with Slovakia (cluster 8). This group of states is distinguished by a low percentage of women working in agriculture (1.1\% on average). The rate of self-employed is very low (merely $12.1 \%$ on average); however, $44 \%$ of them (on average) create additional jobs. Cluster 9 is the biggest with the seven states: Belgium, Ireland, Spain, France, Italy, Cyprus and the United Kingdom. The average rate of female employment in agriculture is rather low (1.4\%) for this group. Other indicators are at an average level in comparison to the other clusters. The last cluster (10) is occupied by five countries: Croatia, Latvia, Lithuania, Portugal, Finland. The average agriculture employment rate is equal to $4 \%$ for this group. We can also observe a high percentage of self-employed $(49.1 \%$ on average) with a rather low share of those self-employed with employees $(10.4 \%$ on average).

Table 1. Compositions of the clusters and average values of the variables

\begin{tabular}{|c|l|c|c|c|c|c|}
\hline Cluster & States & $\begin{array}{c}\text { Var. 1 } \\
\text { EF }\end{array}$ & $\begin{array}{c}\text { Var. 2 } \\
\text { Fem }\end{array}$ & $\begin{array}{c}\text { Var. 3 } \\
\text { Self }\end{array}$ & $\begin{array}{c}\text { Var. 4 } \\
\text { Self2 }\end{array}$ & $\begin{array}{c}\text { Var. 5 } \\
\text { PT }\end{array}$ \\
\hline 1 & Netherlands & $1.2 \%$ & $29.3 \%$ & $52.5 \%$ & $20.5 \%$ & $69.3 \%$ \\
\hline 2 & Austria & $3.6 \%$ & $44.4 \%$ & $57.3 \%$ & $23.2 \%$ & $40.5 \%$ \\
\hline 3 & Malta & $0.3 \%$ & $8.3 \%$ & $50.0 \%$ & $0.0 \%$ & $0.0 \%$ \\
\hline 4 & Romania & $19.2 \%$ & $40.8 \%$ & $36.1 \%$ & $0.5 \%$ & $33.0 \%$ \\
\hline 5 & Luxembourg, Sweden & $0.7 \%$ & $25.9 \%$ & $57.0 \%$ & $41.9 \%$ & $27.2 \%$ \\
\hline 6 & Greece, Poland & $10.1 \%$ & $39.8 \%$ & $64.9 \%$ & $5.8 \%$ & $15.9 \%$ \\
\hline 7 & Bulgaria, Czech Republic, Estonia, Hungary, Slovenia & $2.8 \%$ & $28.6 \%$ & $24.9 \%$ & $10.2 \%$ & $11.0 \%$ \\
\hline 8 & Denmark, Germany, Slovakia & $1.1 \%$ & $24.6 \%$ & $12.1 \%$ & $44.0 \%$ & $25.0 \%$ \\
\hline 9 & Belgium, Ireland, Spain, France, Italy, Cyprus, UK & $1.4 \%$ & $24.0 \%$ & $38.1 \%$ & $17.6 \%$ & $26.6 \%$ \\
\hline 10 & Croatia, Latvia, Lithuania, Portugal, Finland & $4.0 \%$ & $32.4 \%$ & $49.1 \%$ & $10.4 \%$ & $30.6 \%$ \\
\hline
\end{tabular}

Source: own calculation. 


\section{DISCUSSION AND CONCLUSIONS}

The obtained results indicate that female employment in agriculture across the EU is characterised by a high degree of heterogeneity so the research hypothesis was confirmed. Nevertheless, we can observe some regularities. Some of them refer to the similarity between employment in the agriculture sector and employment at the national level. Firstly, the proportion of part-timers in agriculture is related to those at the national level. Secondly, part-time jobs are more common among women. In turn, the feature which distinguishes the analysed sector - the percentage of self-employed in agriculture - is much higher than those employed at the national level.

Poland was assigned to one group with Greece in the received classification. This confirms the findings that the Polish structure of women employment is closer to Mediterranean countries (Szatanderska, Grotkowska, 2009; Matuszewska-Janica, 2016). Female employment in agriculture in both Greece and Poland is distinguished by several factors in comparison to other EU states. Firstly, it contains a high proportion of those employed in agriculture (about $10 \%$ on average) with a relatively small share of part-timers. Secondly, it has a very high rate of self-employed (about $65 \%$ on average) with a very low proportion of those who create jobs for others. In turn, this may be a result of a large share of individual farming (Kryńska, 2007).

At the end it is worth noting that a higher percentage of self-employment with employees (also among women) can be observed in the states with a high level of economic development, in contrast to the states with a worse economic situation. The phenomenon of self-employment seems to be a result of necessity rather than opportunity in the less developed countries, as the authors of the report (European Foundation..., 2017) point out. These results enforce further support for changes in the agricultural sector in the EU new member states, in terms of promoting of the entrepreneurship in particular.

\section{Acknowledgements}

Research is conducted in the frame of project financed by National Science Centre grant 2015/17/B/ /HS4/00930.

\section{REFERENCES}

1. Blau, F.D., Ferber, M.A., Winkler, A.E. (2010). The economics of women, men and work. 6th ed. Pearson Higher, Boston.

2. Clark, C. (1940). The Conditions of Economic Progress. MacMillan, London.

3. European Foundation for the Improvement of Living and Working Conditions (2017). Exploring self-employment in the European Union. Luxembourg: Publications Office of the European Union.

4. Fisher, A.G.B. (1935). The Clash of Progress and Security. MacMillan, London.

5. Gatnar, E., Walesiak, M. (Ed.) (2004). Metody statystycznej analizy wielowymiarowej w badaniach marketingowych [Methods of multivariate statistical analysis in marketing research]. Wydawnictwo AE we Wrocławiu, Wrocław.

6. GEOPA-COPA (2013). Employment in European Agriculture: Labour Costs, Flexibility and Contractual Aspects. Report Ref: VP/2013/001/0080. Institute der deutschen Wirtschaft, Köln.

7. Kanwar, S. (2004). Seasonality and wage responsiveness in a developing agrarian economy. Oxford Bulletin of Economics and Statistics, 66 (2), pp. 189-204.

8. Kaufman, L., Rousseeuw, P.J. (1990). Finding Groups in Data: an Introduction to Cluster Analysis. Wiley, New York.

9. Klepacki, B. (2006). Tendencje zmian w zatrudnieniu i liczbie gospodarstw o zróżnicowanym obszarze w państwach Unii Europejskiej w latach 1990-2003 [Tendency of Change in Employment and Number of Farms in European Union in 1990-2003]. Roczniki Naukowe SERiA, 8 (4), pp. 161-164.

10. Kryńska, E. (2007). Elastyczność zatrudnienia na polskim rynku pracy [Flexible employment and Polish labor market]. Polityka Społeczna, 11-12, pp. 1-8.

11. Krzyżanowska, K. (2014). Sytuacja kobiet na obszarach wiejskich i ich udział w rynku pracy [The situation of women in rural areas and their participation in the labour market]. Problems of Small Agricultural Holdings, 1, pp. 55-67.

12. Kwiatkowska, W. (2012). Bezrobocie w grupach problemowych na rynku pracy w Polsce [Unemployment Among Problem Groups on the Polish Labour Market]. Acta Universitatis Lodziensis Folia Oeconomica, 268, pp. 125-147.

13. Matuszewska-Janica, A. (2016). Wybrane aspekty aktywności zawodowej kobiet w państwach UE: analiza dla lat 2006-2014 [Participation of Women in the La- 
bour market in the Years 2006-2014: EU States Clustering]. Acta Universitatis Lodziensis Folia Oeconomica, 325 (5), pp. 111-126.

14. McQueen, J.B. (1967). Some methods for classification and analysis of multivariate observations. Proceedings of 5th Berkeley Symposium on Mathematical Statistics and Probability. University of California Press, Berkeley.

15. Mularska-Kucharek, M., Wiktorowicz, J. (2015). Entrepreneurship of rural residents in Poland. Acta Scientiarum Polonorum. Oeconomia 14 (3), pp. 83-93.

16. Puzio-Wacławik, B. (2006). Trójsektorowa struktura zatrudnienia w Polsce na tle krajów Unii Europejskiej [A Three-Sector Structure of Employment in Poland as Compared with Other EU Countries]. Zeszyty Naukowe Polskie Towarzystwo Ekonomiczne, 4, pp. 97-111.

17. Rudra, A., Biswas, R. (1973). Seasonality of employment in agriculture. Economic and Political Weekly, 39 (8), pp. A91-A100.

18. rynekpracy.org (2006). Grupy wykluczone. Retrieved from: http://rynekpracy.org/x/235325 [Accessed 14.05.2018].

19. Sawicka, J. (ed.). (2013). Rynek pracy na obszarach wiejskich Mazowsza: perspektywa gender [Labour market in rural areas of Mazovia - gender perspective]. Wydawnictwo SGGW, Warszawa.
20. Szatanderska, U., Grotkowska, G. (2009). Rynek pracy kobiet w Polsce w latach 1992-2007 [The female labour market in Poland in 1992-2007]. In: Kotowska, I.E. (ed.) Strukturalne i kulturowe uwarunkowania aktywności zawodowej kobiet w Polsce [Structural and cultural determinants of economic activity of women in Poland]. Wydawnictwo Naukowe Scholar, Warszawa, pp. 57-98.

21. Szczukocka, A. (2012). Poziom i dynamika zmian zatrudnienia $\mathrm{w}$ sektorze rolnym w Polsce na tle innych państw Unii Europejskiej [Size and changes of employment in the agricultural sector in Poland against a background of these in the other EU member states]. Problemy Rolnictwa Światowego, 12 (2), pp. 114-122.

22. Sztanderska, U. (2006). Działalność organizacji pozarządowych świadczących usługi na rynku pracy skierowane do kobiet [The activities of non-governmental organizations providing services in the labor market aimed at women]. Report of The Foundation for Social and Economic Initiatives (FISE).

23. Walesiak, M. (2006). Rekomendacje w zakresie strategii postępowania $\mathrm{w}$ procesie klasyfikacji zbioru obiektów. In: Zeliaś, A. (Ed.) Przestrzenno-czasowe modelowanie zjawisk gospodarczych. In: Materiały z XXVII Ogólnopolskiego Seminarium Naukowego, Wydawnictwo AE w Krakowie, Kraków, pp. 185-203. 